\title{
Peran Benzyl Amino Purine pada Induksi Tunas Kultur Tembakau White Burley
}

\section{The Role Of Benzyl Amino Purine on Culture Full Induction Tobacco White Burley}

\author{
Dyah Nuning Erawati ${ }^{\#}$, Usken Fisdiana ${ }^{\#}$ dan Siti Humaida

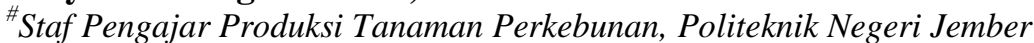 \\ Jalan Mastrip Kotak Pos 164 Jember
}

\begin{abstract}
White Burley tobacco excellence to be developed through tissue culture techniques due to lower nicotine levels and resistance to plant diseases. Obstacles to the development of tobacco culture include the ability of regenerating and differentiating explosive enzymes to form tunas often excessive. Therefore, it is necessary role of exogenous growth regulator of the cytokinin class for the purpose of plant propagation can be achieved with the results of qualified White Burley tobacco seeds. The research was conducted based on Completely Randomized Design with single treatment of Benzyl Amino Purine 0 ppm, 1 ppm, 2 ppm, 3 ppm and 4 ppm. The results of the analysis show that the role of BAP in MS medium influences White Burleypada spurt leaf tobacco, number of shoot and shoot buds. The fastest shoot-forming velocity in the treatment of MS + 3 ppm BAP with an average of 15.75 HST, the highest number of shoots in the treatment of MS +2 ppm BAP with an average of 28,375 shoots and the highest shoots at treatment of MS $+4 \mathrm{ppm} B A P$ with an average of $18,00 \mathrm{~cm}$.
\end{abstract}

Keywords: BAP, bud induction, tobacco culture, White Burley

\section{PENDAHULUAN}

Pertanian tembakau di Jawa Timur setidaknya menyuplai $53 \%$ kebutuhan tembakau nasional dengan nilai investasi sebesar Rp 682 Miliar. Selain itu, potensi pendapatan cukai rokok di Jawa Timur untuk nasional mencapai $78 \%$ dan terdapat 1367 pabrik rokok dengan ribuan karyawan (Kominfo, 2011).Permintaan tembakau di Jawa Timur pada tahun 2010, mencapai 56.020 ton dengan luas areal pengembangan mencapai 66.292 ha. Beberapa jenis tembakau yang dikembangkan di Jawa Timur, meliputi Tembakau Madura, 17.900 ton, Paiton 10.300 ton, Kasturi 7.150 ton, Virginia 8.100 ton dan White Burley 3.370 ton (Disbun Jatim, 2011).

Tembakau White Burley merupakan salah satu jenis tembakau yang digunakan sebagai bahan baku rokok putih dan memiliki kadar nikotin yang lebih rendah dibandingkan dengan jenis tembakau lainnya.Tembakau White Burley adalah galur murni TN 90 yang berasal dari Brazil (Profigen do Brazil Lida) dengan kandungan kadar nikotin yang rendah, yaitu berkisar $2,42 \%-3,58 \%$. Tembakau ini memiliki ketahanan terhadap penyakit layu bakteri yang disebabkan oleh Pseudomonas solanacearum (Rochman et al., 2004).

Menurut Cahyono (2005), krosok daun tembakau White Burley setelah pengolahan menjadi tipis dan berwarna coklat kemerahan sampai coklat, halus dan lunak, beraroma sedap dan memiliki daya hisap terhadap saus cukup besar. Sosok tanaman White Burley dicirikan dengan warna daun hijau pucat (seperti khlorosis)..Senyawa kimia yang terkandung didalam tanaman tembakau White Burley tertera pada tabel 1 .

Tabel 1. Susunan Kimiawi Tembakau White BurLey

\begin{tabular}{llccc}
\hline No & \multicolumn{1}{c}{ Uraian } & \multicolumn{2}{c}{ Jumlah } \\
\hline 1 & Abu & $0,4 \%$ & - & $2,5 \%$ \\
2 & Gula & $0,0 \%$ & - & $0,5 \%$ \\
3 & Fenol & $1 \%$ & - & $2 \%$ \\
4 & Nitrat & & & \\
5 & Nikotin : & $0,16 \%$ & - & $2,89 \%$ \\
& a. Pada daun bawah & $0,3 \%$ & - & $3,75 \%$ \\
& b. Pada daun tengah & $0,5 \%$ & - & $4,0 \%$ \\
& c. Pada daun atas & $0,5 \%$ & - & $3,58 \%$ \\
6 & Kandungan N total & $2,18 \%$ & \\
\hline
\end{tabular}


Bahan tanam merupakan investasi yang penting dalam budidaya tembakau White Burley karena keturunannya merupakan hasil mutan dari jenis Burley. Perbanyakan tanaman tembakau secara generatif akan meningkatkan resiko keragaman dan tidak identik dengan tanaman induk. Selain itu, tembakau merupakan tanaman musiman sehingga pengadaan bahan tanam seringkali terkendala oleh musim yang tidak sesuai.

Salah satu upaya pengadaan bahan tanam tembakau White Burley yang tidak tergantung musim, identik dengan induk, berkualitas tinggi (sehat, bebas serangan hama penyakit dan seragam) serta dalam jumlah banyak adalah dengan perbanyakan secara kultur jaringan. Kultur jaringan merupakan manipulasi pertumbuhan tanaman dalam kondisi yang terkontrol sehingga bagian tanaman beregenerasi menjadi tanaman lengkap. Hasil penelitian Ali et al. (2007) memperlihatkan bahwa perbanyakan massal yang optimal untuk tanaman tembakau varietas K-339 dapat dilakukan secara invitro dengan penambahan BAP 2,0 $\mathrm{mg} / \mathrm{liter}$ dan NAA $0,2 \mathrm{mg} / \mathrm{liter}$.

Kultur jaringan tembakau menghadapi kendala diantaranya adalah kemampuan eksplan beregenerasi dan berdiferensiasi untuk membentuk tunas yang berlebihan. Seringkali tunas yang terbentuk dari inisiasi jaringan vegetatif mengalami pertumbuhan luar biasa, bergerombol dan abnormal sehingga meningkatkan resiko variasi keragaman dalam upaya mikropropagasi tembakau White Burley. Oleh karena itu, penambahan zat pengatur tumbuh dalam golongan sitokinin diperlukan agar tujuan dari perbanyakan dapat tercapai dengan hasil bibit tembakau White Burleyberkualitas tinggi.

\section{METODOLOGI}

Penelitian dilaksanakan di laboratorium Kultur Jaringan Politeknik Negeri Jember dengan ketinggian 89 meter dpl., bulan Mei - Desember 2016. Penelitian disusun berdasar Rancangan Acak Lengkap faktor tunggal dengan 5 ulangan. Faktor tunggal berupa penambahan Benzyl Amino Purinedalam media dasar Murishage-Skoog yang terdiri atas beberapa konsentrasi :

1. Media MS + BAP 0 ppm

2. Media MS + BAP 1 ppm

3. Media MS + BAP 2 ppm

4. Media MS + BAP 3 ppm

5. Media MS + BAP 4 ppm

Pelaksanaan penelitian terdiri atas :

1. Pembuatan Media Tanam

Larutan stok MS dibuat dengan menimbang zat-zat dengan konsentrasi sesuai. Media dibuat dengan menambahkan larutan stok hara makro, hara mikro, vitamin, asam amino, gula dan BAP sesuai perlakuan serta penetapan $\mathrm{pH}$ 5,7 - 5,8 kemudian ditambahkan agar-agar.

$$
\text { 2. Persiapan Eksplan }
$$

Eksplan yang digunakan berupa daun nomor 2 dan 3 termuda dari tanaman tembakau White Burley yang telah dilakukan perawatan sebelumnya. Tanaman yang digunakan sebagai eksplan diseleksi terlebih dahulu untuk mendapatkan bibit yang unggul. Tanaman yang diambil adalah tanaman yang terbaik serta sehat dan bebas dari patogen.

3. Sterilisasi Eksplan

Eksplan yang telah disiapkan kemudian dicuci dengan air mengalir hingga bersih. Selanjutnya eksplan daun tembakau direndam dan digojog diatas shaker dalam larutan tween 80 kemudian eksplan disterilisasi dalam larutan fungisida dan bakterisida $1,5 \%$ dan eksplan dibilas sampai bersih. Didalam Laminar, eksplan direndam dalam larutan alkohol 70 $\%$ kemudian dibilas dengan aquades steril. Eksplan disterilisasi dalam larutan klorok $10 \%$ selama kemudian dibilas lagi dengan akuades steril.

$$
\text { 4. Isolasi Eksplan }
$$

Kegiatan induksi tunas tembakau ini dilaksanakan di ruang tanam dalam laminar air flow cabinet. Eksplan berupa daun muda dipotong diatas petridish lalu ditanam pada media. Setiap botol ditanam 3 ekslpan. Botol diberi label sesuai perlakuan dan ulangan.

\section{Inkubasi Eksplan}

Eksplan di inkubasi dalam kondisi suhu, cahaya dan kelembaban yang sama. Suhu yang digunakan yaitu $26 \pm 2^{\circ} \mathrm{C}$, kelembaban $70 \%$ serta lamanya penyinaran 12 jam terang.

6. Pengamatan

Parameter pengamatan terdiri atas kecepatan bertunas (hari), jumlah tunas (tunas) dan tinggi tunas (cm).

\section{HASIL DAN PEMBAHASAN Kecepatan Bertunas}

Eksplan yang membentuk kalus bisa memproduksi meristemoid yang akan tumbuh menjadi tunas (organogenesis). Kecepatan pembentukan tunas yang ditandai dengan awal pembentukan tunas yang berwarna hijau tertera pada tabel 1.

TABel 1. Respon PenAmbahan BAP TerhadaP Kecepatan Pembentukan Tunas TembaKau White BURLEY

\begin{tabular}{cc}
\hline Perlakuan & Kecepatan bertunas (hari) \\
\hline P1 & $0,000 \mathrm{a}$ \\
\hline P2 & $16,000 \mathrm{~b}$ \\
\hline P3 & $17,500 \mathrm{~b}$ \\
\hline P4 & $15,750 \mathrm{~b}$ \\
\hline P5 & $17,250 \mathrm{~b}$ \\
\hline
\end{tabular}


Dyah Nuning Erawati, Usken Fisdiana dan Siti Humaida. Peran Benzyl Amino Purine pada Induksi

Tunas Kultur Tembakau White Burley

Keterangan : Huruf yang sama pada satu kolom menunjukkan angka yang berbeda tidak nyata berdasarkan uji BNT $5 \%$

Respon eksplan terhadap penambahan zat pengatur tumbuh BAP 3,0 ppm kedalam media tanam menunjukkan kecepatan bertunas yang paling cepat rata-rata 15,75 hari dan berbeda tidak nyata dengan perlakuan P2, P3 dan P5 (BAP 1 ppm, 2 ppm dan $4 \mathrm{ppm}$ ). Pembentukan tunas paling lambat dan tidak mampu bertunas ditunjukkan pada perlakuan P1 (BAP0,0 ppm ) yang berbeda nyata dengan semua perlakuan.

Komposisi dan konsentrasi hormon pertumbuhan yang ditambahkan dalam media sangat mempengaruhi arah pertumbuhan dan regenerasi eksplan yang dikulturkan. Golongan sitokinin yang umum digunakan adalah BA (6-Benzyl Adenine) dan Kinetin. Golongan ini sangat penting dalam pengaturan sel dan morfologis (Gunawan, 1995). Sitokinin dalam budidaya jaringan terbukti dapat memacu diferensiasi tunas. Tunas dapat tumbuh dari jaringan kalus, daun, potongan batang atau kotiledon. Hasil percobaan terbukti bahwa $75 \%$ species tanaman membentuk tunas jika menggunakan kinetin atau benzilaminopurin dengan konsentrasi antara 0,5 - $46 \mathrm{uM}$ (Hendaryono dan Wijayani, 2007).

\section{Jumlah Tunas}

Eksplan yang berasal dari jaringan meristem seperti daun tembakau yang masih muda lebih mudah tumbuh dan beregenerasi karena memiliki sel-sel yang aktif membelah dengan dinding sel yang belum kompleks sehingga lebih mudah dimodifikasi dalam kultur. Hasil uji beda rata-rata respon eksplan dengan penambahan $\mathrm{BAP}$ terhadap jumlah tunas yang terbentuk tertera pada tabel 2 .

TABel 2. ResPon PENAMbahan BAP TERHADAP Jumlah Tunas Tembakau White BuRLEY

\begin{tabular}{cc}
\hline Perlakuan & Jumlah tunas (tunas) \\
\hline P1 & $0,000 \mathrm{a}$ \\
\hline P2 & $22,125 \mathrm{~b}$ \\
\hline P3 & $28,375 \mathrm{~b}$ \\
\hline P4 & $22,375 \mathrm{~b}$ \\
\hline P5 & $16,125 \mathrm{~b}$ \\
\hline
\end{tabular}

Keterangan : Huruf yang sama pada satu kolom menunjukkan angka yang berbeda tidak nyata berdasarkan uji BNT 5\%

Berdasar hasil analisis sidik ragam diketahui bahwa penambahan zat pengatur tumbuh dari golongan BAP memberikan pengaruh yang berbeda nyata terhadap jumlah tunas tembakau. Hal ini memperlihatkan bahwa penambahan konsentrasi BAP dalam media memberikan kemampuan eksplan tembakau untuk membentuk banyaknya tunas.

Berdasarkan Tabel 2 terlihat bahwa rerata jumlah tunas yang terbentuk paling banyak terdapat pada perlakuan P3 (BAP $2.0 \mathrm{ppm}$ ) yaitu 28,375 tunas yang berbeda tidak nyata dengan perlakuan P2, P4, P5 tetapi berbeda dengan perlakuan P1. Pada perlakuan P1 tidak tumbuh tunas karena tidak ada penambahan zat pengatur tumbuh didalam media tanam. Hal ini menunjukkan bahwa kandungan sitokinin endogen pada eksplan tembakau tidak terpenuhi meskipun eksplan diambil dari daun muda tembakau White Burley yang cenderung masih bersifat meristematis.

Pertumbuhan dan morfogenesis dalam kultur jaringan sangat dipengaruhi oleh keadaan jaringan tanaman yang digunakan sebagai eksplan. Selain faktor genetis eksplan yang telah disebutkan di atas, kondisi eksplan yang mempengaruhi keberhasilan kultur adalah jenis eksplan, ukuran, umur dan fase fisiologis jaringan yang digunakan sebagai eksplan.

Umur eksplan sangat berpengaruh terhadap kemampuan eksplan tersebut untuk tumbuh dan beregenerasi. Umumnya eksplan yang berasal dari jaringan tanaman yang masih muda (juvenil) lebih mudah tumbuh dan beregenerasi dibandingkan dengan jaringan yang telah terdiferensiasi lanjut. Jaringan muda umumnya memiliki sel-sel yang aktif membelah dengan dinding sel yang belum kompleks sehingga lebih mudah dimodifikasi dalam kultur dibandingkan jaringan tua. Oleh karena itu, inisiasi kultur biasanya dilakukan dengan menggunakan pucuk-pucuk muda, kuncup-kuncup muda, hipokotil, inflorescence yang belum dewasa, dll. Jika eksplan diambil dari tanaman dewasa, rejuvenilisasi tanaman induk melalui pemangkasan atau pemupukan dapat membantu untuk memperoleh eksplan muda agar kultur lebih berhasil (Chalwa, 2004).

\section{Panjang Tunas}

Pertumbuhan dan morfogenesis dalam kultur jaringan sangat dipengaruhi oleh keadaan jaringan tanaman yang digunakan sebagai eksplan. Panjang tunas tembakau yang terbentuk pada eksplan menunjukkan bahwa penambahan BAP pada beberapa konsentrasi mempengaruhi panjang tunas secara nyata. Hal ini diduga berhubungan dengan pengaruh genetis tembakau yang digunakan sebagai eksplan. Menurut Trigiano dan Gray (2000), perbedaan respon genotip tanaman dapat terjadi pada pembentukan kalus, laju pertumbuhan kalus serta regenerasi kalus menjadi tanaman lengkap baik melalui pembentukan organ-organ adventif maupun embrio somatik. Regenerasi dan perkembangan organ adventif dan somatic embrio juga sangat ditentukan oleh varietas tanaman induk. Perbedaan pengaruh genetik ini disebabkan karena perbedaan kontrol genetik dari masing-masing varietas serta 
jenis kelamin tanaman induk.Rata-rata panjang tunas yang terbentuk pada eksplan tembakau tertera pada tabel 4.

TABel 4. Respon PENAMbahan Kinetin TERHADAP PANJANG TUNAS TEMBAKAU White BURLEY

\begin{tabular}{cc}
\hline Perlakuan & Panjang tunas $(\mathrm{cm})$ \\
\hline P1 & $0,000 \mathrm{a}$ \\
\hline P2 & $0,941 \mathrm{a}$ \\
\hline P3 & $17,750 \mathrm{~b}$ \\
\hline P4 & $16,375 \mathrm{~b}$ \\
\hline P5 & $18,000 \mathrm{~b}$ \\
\hline
\end{tabular}

Keterangan : Huruf yang sama pada satu kolom menunjukkan angka yang berbeda tidak nyata berdasarkan uji BNT 5\%

Berdasarkan Tabel 4 terlihat bahwa rerata panjang tunas yang terbentuk paling tinggi terdapat pada perlakuan P5 (BAP4,0 ppm) yaitu 18,000 cm yang berbeda tidak nyata dengan perlakuan P3 dan P4 tetapi berbeda nyata dengan perlakuan P1 dan P2. Perlakuan P1 berbeda tidak nyata dengan perlakuan P2 (BAP 1,0 ppm ppm).

BAP termasuk dalam golongan sitokinin yang berperan dalam mengatur pembelahan sel, pembentukan organ, pembentukan kloroplas dan perkembangan mata tunas atau pucuk ( Setyadi, 2009). Hasil penelitian Nisak, dkk. (2012) menunjukkan bahwa kombinasi ZPT NAA 1 ppm dan BAP 4 ppm memberikan hasil proliferasi tunas yang tertinggi pada kultur jaringan tembakau varietas Prancak-95.

Pembelahan sel dalam kultur in vitro tanaman yang disebabkan oleh zat pengatur tumbuh sitokinin banyak digunakan untuk induksi kalus dan regenerasi tunas. Sitokinin sebagai zat pengatur tumbuh mempunyai berbagai fungsi antara lain :

1. Sitokinin berperan dalam memacu perkembangan, pembesaran, dan pembelahan sel serta berperan dalam penundaan senescence (penuaan), dengan jalan sitokinin menghambat penguraian protein.

2. Sitokinin berperan mengarahkan transport hara, yaitu memberi signal ke arah mana zat hara akan dibawa atau ditransport.

3. Sitokinin juga berperan mendorong proses morfogenesis, pertunasan, pembentukan kloroplas, pembentukan umbi pada kentang, pemecahan dormansi, pembukaan stomata, dan pembungaan.

4. Sitokinin dapat menstimulir terjadinya pembelahan sel, proliferasi kalus, pembentukan tunas, mendorong proliferasi meristem ujung, menghambat pembentukan akar, dan mendorong pembentukan klorofil pada kalus (Santoso dan Nursandi, 2001).

Pertumbuhan dan morfogenesis dalam kultur jaringan sangat dipengaruhi oleh keadaan jaringan tanaman yang digunakan sebagai eksplan. Selain faktor genetis eksplan yang telah disebutkan di atas, kondisi eksplan yang mempengaruhi keberhasilan kultur adalah jenis eksplan, ukuran, umur dan fase fisiologis jaringan yang digunakan sebagai eksplan.

Ukuran eksplan juga mempengaruhi keberhasilan kultur. Eksplan dengan ukuran kecil lebih mudah disterilisasi dan tidak membutuhkan ruang serta media yang banyak, namun kemampuannya untuk beregenerasi juga lebih kecil sehingga dibutuhkan media yang lebih kompleks untuk pertumbuhan dan regenerasinya. Sebaliknya semakin besar eksplan, maka semakin besar kemungkinannya untuk membawa penyakit dan makin sulit untuk diterilkan, membutuhkan ruang dan media kultur yang lebih banyak. Ukuran eskplan yang sesuai sangat tergantung dari jenis tanaman yang dikulturkan, teknik dan tujuan pengkulturan.

\section{KESIMPULAN DAN SARAN \\ Kesimpulan}

Berdasarkan hasil analisis dan pembahasan, maka dapat disimpulkan:

1. Peran penambahan BAP dalam media dapat memicu induksi tunas tembakau White Burley dengan memberikan pengaruh nyata terhadap kecepatan bertunas, jumlah tunas dan tinggi tunas.

2. Kecepatan bertunas yang paling cepat pada penambahan BAP 3,0 ppm sedangkan jumlah tunas terbanyak pada penambahan BAP 2,0 ppm serta panjang tunas terbaik pada penambahan BAP 4,0 ppm.

\section{SARAN}

Perlu penelitian lebih lanjut untuk menguji kriteria tunas yang berpotensi menghasilkan perkembangan planlet yang sehat, normal dan seragam.

\section{DAFTAR PUSTAKA}

[1] Ali, G et al,. 2007. Callus Induction and in vitro Complete Plant Regeneration of Different Cultivars of Tobacco (Nicotiana tabacum L.) on media of Different Hormonal Concentration. Journal of Biotechnology. 6 (4).

[2] Bidang Produksi Dinas Perkebunan Provinsi Jawa Timur. 2009. Petunjuk Teknis Budidaya Tembakau.. Dinas Perkebunan Povinsi Jawa Timur.

[3] Cahyono, Bambang. 2005. Tembakau Budidaya dan Analisis Usaha Tani. Yogyakarta: Kanisius.

[4] Chawla, H.S., 2004. Introduction to plant biotechnology. 2nd ed. Science publishers,Inc. New Hampshire

[5] Dinas Komunikasi dan Informatika Jatim. 2011. Permintaan Tembakau Oleh Pabrik Rokok. http://www.dinasinfokom-jatim. Diakses 16 Maret 2017. 
Dyah Nuning Erawati, Usken Fisdiana dan Siti Humaida. Peran Benzyl Amino Purine pada Induksi Tunas Kultur Tembakau White Burley

[6] Daisy, P. Sriharyanto dan Ari Wijayani. 2007. Teknik Kultur Jaringan. Yogyakarta: Kanisius.

[7] Gunawan, Winata. 1995. Teknik Kultur Jaringan Tumbuhan. Bogor : Departemen Pendidikan dan Kebudayaan Direktorat Jendral Pendidikan Tinggi Pusat Antara Universitas Bioteknologi Intitut Pertanian Bogor.

[8] Ibrahim, M. S. Dewi, Kristina M. N. Bermawie N. 2004. Studi Pendahuluan: Induksi Kalus Embriogenik dari Daun Echinaceae purpurea. Buletin TRO Vol. XV No 2. 2004.

[9] Kominfo Jatim. 2010. Luamajang Targetkan 3.370 ton Tembakau White Burley. Dinas Komunikasi dan Informasi Provinsi Jawa Timur

[10] Nisak, Nurhayati dan Kristari Purwani. 2012. Pengaruh Kombinasi Zat Pengetaur Tumbuh NAA dan BAP pada Kultur Jaringan Tembakau var. Prancak-95. Jurnal Sains dan Seni POMITS. Vol 1 No. 1

[11] Rochman dkk,. 2004. Deskripsi Tembakau Burley Varietas TN 90 (Galur Murni). (Tidak Dipublikasikan).

[12] Santoso, U dan Nursandi. F. 2001. Kultur Jaringan Tanaman. Malang :Universitas Muhammadiyah Malang Press

[13] Setyadi, S. 2009. Zat Pengatur Tumbuh Pengenalan dan Petunjuk Penggunaan pada Tanaman.. Bogor: 2009.

[14] Taji, A., P. Kumar and P. Lakshmanan, 2002. In vitro plant Breeding. The Haworth Press, Inc. New York.

[15] Trigiano, R.N. \& D.J. Gray, 2000. Plant Tissue culture concepts and laboratory exercises. 2nd Adt. CRC Press. New York 